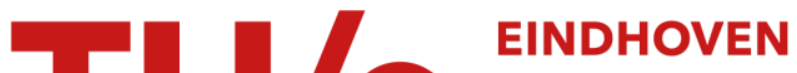 UNIVERSITY OF TECHNOLOGY
}

\section{Institutional 'lock-out' towards local self-governance?}

\section{Citation for published version (APA):}

Breukers, S. C., Mourik, R. M., van Summeren, L. F. M., \& Verbong, G. P. J. (2017). Institutional 'lock-out' towards local self-governance? Environmental justice and sustainable transformations in Dutch social housing neighbourhoods. Energy Research and Social Science, 23, 148-158. https://doi.org/10.1016/j.erss.2016.10.007

DOI:

10.1016/j.erss.2016.10.007

Document status and date:

Published: 01/01/2017

\section{Document Version:}

Typeset version in publisher's lay-out, without final page, issue and volume numbers

\section{Please check the document version of this publication:}

- A submitted manuscript is the version of the article upon submission and before peer-review. There can be important differences between the submitted version and the official published version of record. People interested in the research are advised to contact the author for the final version of the publication, or visit the $\mathrm{DOI}$ to the publisher's website.

- The final author version and the galley proof are versions of the publication after peer review.

- The final published version features the final layout of the paper including the volume, issue and page numbers.

Link to publication

\section{General rights}

Copyright and moral rights for the publications made accessible in the public portal are retained by the authors and/or other copyright owners and it is a condition of accessing publications that users recognise and abide by the legal requirements associated with these rights.

- Users may download and print one copy of any publication from the public portal for the purpose of private study or research.

- You may not further distribute the material or use it for any profit-making activity or commercial gain

- You may freely distribute the URL identifying the publication in the public portal.

If the publication is distributed under the terms of Article 25fa of the Dutch Copyright Act, indicated by the "Taverne" license above, please follow below link for the End User Agreement:

www.tue.nl/taverne

Take down policy

If you believe that this document breaches copyright please contact us at:

openaccess@tue.nl

providing details and we will investigate your claim. 
Original research article

\title{
Institutional 'lock-out' towards local self-governance? Environmental justice and sustainable transformations in Dutch social housing neighbourhoods
}

\author{
S. Breukers ${ }^{\mathrm{a}, *}$, R.M. Mourik ${ }^{\mathrm{a}}$, L.F.M. van Summeren ${ }^{\text {a }}$, G.P.J. Verbong ${ }^{\mathrm{b}}$ \\ a DuneWorks/Technical University of Eindhoven (TU/e), Eindhoven, the Netherlands \\ ${ }^{\mathrm{b}}$ Technical University of Eindhoven (TU/e), Eindhoven, the Netherlands
}

\section{A R T I C L E IN F O}

\section{Article history:}

Received 8 April 2016

Received in revised form 18 October 2016

Accepted 18 October 2016

Available online $\mathrm{xxx}$

Keywords:

Environmental justice

Energy efficiency

Path-dependency

Institutions

Neighbourhood

Social housing

\begin{abstract}
A B S T R A C T
In their efforts to improve social housing neighbourhoods, Dutch housing associations attempt to encourage tenants to take a more active role. Generally speaking, bottom-up initiatives and participatory approaches have become popular among Dutch policy-makers as ways to achieve sustainable energy goals. While the rise of local energy cooperatives seems to support this view, we also see that particularly in deprived neighbourhoods, there is no bottom-up activity, nor will it occur without external support. This paper thus examines a case of an externally initiated programme in a Dutch social housing neighbourhood, aiming to place tenants' needs at the centre. Applying an environmental justice framework, we address both the historical-institutional legacies and the tenants' positions, showing how institutional pressures built up over time have resulted in a diluting of the programme into a top-down technology-pushed approach. The relevance goes beyond this case: without ensuring the quality of the participation, institutional lock-ins can produce perverse outcomes, with the programme failing to achieve its (energy-efficiency) goals while the intended beneficiaries lose out. As a counterweight, an active process of capacity building is proposed, using an environmental justice approach to examine the conditions for local self-governance and how to address these in a participatory intervention.
\end{abstract}

(C) 2016 Published by Elsevier Ltd

\section{Active citizens and local sustainable innovation}

Local bottom-up initiatives and participatory approaches are increasingly regarded as solutions for various implementation problems in the areas of renewable energy generation, energy saving and efficiency improvements, both in the Netherlands and across Europe [13]. Examples of citizens who organise themselves 'bottom-up' to collectively solve societal problems at a neighbourhood level have stirred enthusiasm among policy makers [29,52]. The resulting Dutch 'participatory society' policy discourse, in some ways similar to the British 'Big Society' discourse, has however invoked criticism from those warning that initiatives that are distributed unevenly across society cannot be expected to serve as an alternative to the withdrawing welfare state $[25,13,31,47]$. In addition, the participatory society-discourse reflects a rather instrumental view of the citizens involved and is based on assumptions about upscaling early-mover best practices in laggard neighbourhoods. However, such trickle down effects are unlikely to occur. In fact, in many neighbourhoods, especially deprived ones facing a lack of resources (financial, time, relational) and/or capabilities, no bottom-up activity is occurring at all (or not the kind that policymakers would like to see), nor will it occur without support from external (public) organisations.

\footnotetext{
* Corresponding author.

Email addresses: sylvia.breukers@duneworks.nl (S. Breukers); ruth.mourik@, duneworks.nl (R.M. Mourik); luc@duneworks.nl (L.F.M. van Summeren); g.p.j. verbong@tue.nl (G.P.J. Verbong)
}

In academic literature, there also seems to be great interest in bottom-up initiatives, judging by the growing number of studies on the dynamics of grass-roots level self-mobilisation of communities, making use of theoretical concepts drawn from socio-technical innovation and transition literature [36-37, 3938]. Without denying the importance of these studies, our observation is that we also need to focus on the numerous situations where no grass-roots dynamics seem to occur. In such cases, external initiative can in principle encourage local mobilisation and participation. However, this raises questions regarding the roles of and the relations between the initiator and residents and how these can change during the process. After all, an external initiative involves a risk, that instead of working towards locally relevant goals, the participation increasingly aims at getting people to commit to ideas 'from outside'. A lack of recognition of local needs undermines the quality of the participatory process. In fact, occurrences of clashes between supra-local sustainability goals and local (sustainability) goals and needs are well-documented and usually relate to a lack of recognition of the latter by the project initiators $[8,23,44,51]$.

We have identified several elements that require attention when scrutinizing externally initiated programmes aimed at neighbourhood improvements: the quality of the participation process, the recognition of local (and heterogeneous) goals and needs, the distribution of benefits and disadvantages, and the extent to which capabilities and resources are sufficiently present among residents locally to be able to voice concerns. The latter aspect is especially important when addressing deprived neighbourhoods. The concept of environmental 
justice is a very suitable evaluative framework; it offers the opportunity to engage with and reveal the relational and power-laden dimensions of externally initiated efforts at sustainability innovations as they unfold locally and affect (and are affected by) peoples' daily lives.

In recent years, the environmental justice concept has evolved to analyse and evaluate issues, especially in the dynamics of our energy systems regarding the relationship between energy concerns and well-being $[2,322,26,19,40,49]$. Our aim is to contribute to this literature, by taking a closer look at initiatives targeting sustainable improvements in deprived neighbourhoods.

In the Netherlands, the majority of the lowest-income households live in social housing. Of the three million rented homes in the Netherlands, around $75 \%$ are owned by housing associations, semi-public organisations assigned to provide affordable rental housing (state-subsidized). ${ }^{1}$ National government sets the rules for social housing allocation and stipulates the responsibility of the housing associations, which includes maintaining or improving the quality of neighbourhoods.

In their efforts to improve neighbourhoods, Dutch housing associations are increasingly looking for innovative ways to mobilise residents, to trigger active participation so that residents themselves take a more active role and responsibility in improving their neighbourhood. This signals the intention to move away from more traditional approaches that aim at acceptance of ready-made solutions (energy efficiency improvements through renovation) devised for social housing neighbourhoods. Acknowledgement is now growing that such approaches do not result in desired acceptance levels. Large-scale retrofitting programmes in social housing neighbourhoods must be legally approved by $70 \%$ of the tenants, which can be quite a challenge. But even when such retrofitting has taken place, the envisaged energy performance improvements may not transpire - e.g. if residents do not use the innovative ventilation systems as intended [1,9,30,42].

The case in this paper is about the Airey neighbourhood in the Dutch city of Eindhoven. It is exemplary with regard to the sort of challenges many deprived neighbourhoods are facing: degraded housing stocks, high energy bills, low comfort levels due to low energy efficiency, socio-economic decline, little social cohesion, problems like indebtedness, addiction and long-term unemployment.

In line with its short term strategy for the period 2013-2017 explicitly aiming for a more demand-driven approach to neighbourhood improvement [5], housing association Woonbedrijf developed the so-called "Neighbourhood Transformation" approach, focusing on renovation and improved energy efficiency. The idea was that the programme would be co-created with and at some point handed over to the local neighbourhood community. However, these aims did not materialise in practice, raising the question why it proved to be so difficult. A central question therefore is what challenges such an externally initiated programme faces. Based on our analysis of these challenges, the question how to stop it diluting into a top-down technology-pushed approach (which happened in this case) is asked. The aim of this inquiry is to learn how a top-down programme (by a public actor like a housing association or municipality) can become more effective in supporting a local capacity building process for self-governance - particularly in local contexts where such capacities are absent. We will provide an evaluative account and point out how this case analysis is relevant to similar contexts (low-income neighbourhoods with little self-mobilisation and requiring sustainable improvements) in the Netherlands, but arguably elsewhere in Europe too. We furthermore aim to formulate practical recommendations for future interventions in similar contexts elsewhere.

\footnotetext{
${ }^{1}$ https://www.government.nl/topics/housing/contents/housing-associations
}

\section{Conceptualising local action in complex domains}

\subsection{Path-dependency and rules of engagement}

A central point of departure for the intervention in the Airey neighbourhood was improving energy efficiency. Energy-related interventions affect and are affected by a variety of policy domains besides energy policy, including: housing (energy efficient homes and local renewables generation), social policy (local self-governance in micro-grids), spatial planning (planning, zoning), environmental policy (climate change policies, energy efficiency targets) and fiscal policies (green tax reforms) etc. Furthermore, multiple scales of policy and decision-making, diverse (networks of) actors with different needs, various interdependencies and incumbent 'ways of doing' present challenges to change $[22,44]$.

The domain of energy, like housing, is socio-technical in nature - involving physical objects, infrastructure, institutions, actors, networks and social norms that have co-evolved over time [20]. This historical co-evolution is captured by the notion of path-dependency, which rejects the idea that the same forces will give similar results in different places at different times [43]. In other words, context matters, and as part of this context, institutions play a crucial role - being the formal and informal rules of behaviour [33,24]. Institutions like shared norms, policies and regulations contribute to reproducing ways of doing at various levels in organisations and in society, even when it is clear that these practices are not sustainable. This reproduction is captured by the concept of lock-in $[27,46]$. A lock-in refers to a perpetuation of 'choice' favouring particular options, while arguably better alternatives are available. The sources of lock-in can be technical, physical, institutional, social and organisational [46]. Socio-technical governance processes often merely strengthen the existing organisation of power in a particular context, but they may also challenge it and thus contribute to a 'lock-out' $[27,10,41]$. By 'lock-out' we refer to a process of becoming aware of the seemingly self-evident perpetuation of certain trajectories, followed by efforts to change this. Such efforts should then probably target the sources of lock-in, which are institutional, physical, social, or a combination of these.

The point we are trying to make is that what happens in local contexts is highly influenced by arrangements and institutions on higher scale levels. At neighbourhood level, it is relevant to focus on path-dependent developments from various domains in order to learn how these have contributed to - in our case - the failure of a housing association's aim to work in a more participatory and demand-driven manner.

Socio-ecological systems research draws attention to institutional contexts and how these enable local (self)governance [21]. It focuses on issues of adaptive and inclusive governance of complex systems and highlights those organisational structures in society that define our ways of doing at a local level. It emphasises that local self-governance arrangements need to be supported by higher-level institutions that enable local adaptive self-governance [15]. This literature argues against a hierarchic and uni-centric view on governance, which considers private or state actors best able to sustainably manage our socio-ecological systems. Instead, polycentric systems of rules (with larger, medium and small-scale decentralized units of governance) are proposed to improve and maintain our socio-ecological systems and the services they provide to citizens. The crux is that citizens have to be involved in producing those rules if we want to solve collective action problems [15,21,43].

Research has shown that the rules of engagement are indeed part of the problem: often it is not the technology or project, but the 
process itself that triggers local resistance due to being regarded unfair $[23,10]$. The way the process allows for co-deciding or negotiating the conditions under which the proposed interventions are acceptable for those directly involved and affected, will influence the perceived acceptability of outcomes. In other words: the procedural and outcome justice dimensions are closely interlinked [23]. Addressing these fairness-perceptions regarding process and (envisaged) outcomes enables a 'demand-side' analysis of the intended demand-driven approach initiated by the housing association. We first briefly introduce the environmental justice framework that we have adopted for this purpose.

\subsection{Environmental justice: understanding power in participation}

Democratic and participatory decision-making procedures are both an element of, and a condition for, social justice [34]. The literature on environmental justice has concentrated on the notion of distributive justice, which refers to equity in the distribution of environmental risk and in the distribution of environmental 'goods' and 'bads'. However, recent work has broadened the constitutive elements of environmental justice, resulting in more pluralist understandings (for a discussion of perspectives on environmental justice, we refer to [35] and [2]). In addition to distributional issues, two additional dimensions of justice have been highlighted as equally important for a process where the rules of engagement actually engage end-users. First, recognition of the diversity of the participants and their needs, ambitions and experiences. Instead of taking an idealist perspective that assumes recognition of diversity, Schlossberg argues for investigating this in real-life situations, in order to recognise and understand the diversity of those affected by a particular distribution of goods and bads [34]. Equal recognition then is a prerequisite for fair distribution [2]. Second, also strongly associated with recognition, is participation in the political process. If someone is not recognised, (s)he will not be invited to participate.

This pluralist perspective allows us to focus on the process as a way of addressing both the conditions undermining social recognition and the resulting (in)equitable distribution [34]. It furthermore calls attention to context, acknowledging that there is no universally applicable prescription for a fair distribution of environmental quality and a fair process [48]. Assessing whether a situation of inequity is unfair, depends on the particular context and actors involved.

Context also refers to spatial and time dimensions, which is relevant when addressing neighbourhoods as part of cities. Most cities in the world share a characteristic, namely large inequalities between their inhabitants [2]. Geographically, they become visible when neighbourhoods or districts face deprivation. Interventions in such neighbourhoods, aimed at redressing of inequalities regarded as unfair or unjust, are interesting to investigate because they do not take place in a void. Recent work by Davoudi and Bell connects theories of environmental justice to discussions on justice and the city, regarding the city as a (...) "social and political space that is actively reproducing (in)justices" ([2]:349). While our case is a neighbourhood, the interventions relate considerably to the level of city policy and politics.

Davoudi and Brooks [11] extended the environmental justice framework by adding two more dimensions - capability and responsibility - to the three dimensions of distribution, recognition and participation. Capability refers to the capacities and ability of communities and individuals to function and flourish. Taking responsibility for other humans, society and non-human nature at individual and collective levels relates to structural and institutional contexts, physical and mental vulnerabilities, social norms and cultural values [11]. They summarise the pluralistic environmental justice approach as follows: "The focus is not only on who gets what, but also on who counts, who gets heard, what matters and who does what" [12]. We have drawn on their approach and the questions they formulated for each of the five dimensions of environmental justice for our case (Table 1). We were thus able to analyse and qualify the uptake and efforts to adopt a more demand-driven approach.

\section{Research methodology}

Basically, two research strategies have been combined in an in-depth single case study [4]. First, we use a retroductive research strategy that takes a theoretical starting point to structure the empirical inquiry, after which the theoretical ideas are confirmed or adapted. In our case, this means we propose explanatory mechanisms (path-dependent processes that can cause lock-ins) to account for certain outcomes (failure of a demand-driven innovative transformative approach), followed by attempts to establish whether this postulated mechanism operates in the manner suggested and the potential consequences of such interventions in similar contexts. We present an ex-post case study (Section 4), structured as a historical-institutional analysis of the neighbourhood, its residents and past interventions until 2014, based on empirical materials derived from (policy) documentation, websites and additional information gathered during interviews and informal talks (see Table 3).

Second, we adopt an abductive strategy. It is a constructivist strategy that takes a more grounded approach, whereby empirical material (and not theory) serves as point of departure. Social scientific accounts are generated from people's everyday accounts [4]. In our case these are based on the data collected (see Table 3) during field work in the neighbourhood (Section 5).

As starting point to address the environmental justice dimensions, we identified broad segments of very different types of the resident Aireys population in terms of backgrounds, demographics, ambitions, needs and capabilities. In addition, we analysed interviews using the categories listed in Table 2 below, in order to generate accounts of how residents view the quality of their homes, the neighbourhood, public spaces, their relationships with one another and with the housing associations and other organisations. Using these, we attempted to reconstruct residents' perspectives and positions.

The fieldwork consisted of participant observation, interviews and informal talks. A total of 64 brief semi-structured interviews with the residents were held on their doorstep and sometimes in their home. ${ }^{2}$ We asked people how they were doing and addressed the categories in Table 3. We managed to interview $30.5 \%$ of all the households in the Airey neighbourhood. In addition, we conducted 11 interviews as well as many informal talks with housing association Woonbedrijf staff, the municipality of Eindhoven, the neighbourhood police officer and representatives of technologically-innovative companies that collaborate with the city of Eindhoven and Woonbedrijf.

Our role as action researchers was such that we were both investigating and advising Woonbedrijf. Our advisory role was agreed in a contract stipulating our collaboration as part of a Dutch government-funded research project. This advisory role gave us a rather unique view on and access to various internal discussions. The interviews with the neighbourhood residents were performed both for this research project and for Woonbedrijf, at a time when their Neighbourhood Transformation approach was facing problems.

${ }^{2}$ We did the interviews together with Frank Metsemakers from KAW consultants [28]. 
Table 1

Questions for each of the 5 environmental justice dimensions.

\begin{tabular}{|c|c|}
\hline $\begin{array}{l}\text { Justice } \\
\text { dimensions }\end{array}$ & Questions relevant for the Aireys: \\
\hline 1. Recognition & $\begin{array}{l}\text { - Are all residents of the neighbourhood recognized, is anyone } \\
\text { excluded? } \\
\text { - How are the residents of the neighbourhood recognized in their } \\
\text { diversity (of perspectives, needs, ambitions, expectations)? }\end{array}$ \\
\hline 2. Participation & $\begin{array}{l}\text { - How are the residents involved in defining needs, solutions, } \\
\text { and priorities in various stages of the process? } \\
\text { - How are they involved in setting out the rules of engagement } \\
\text { of the process? }\end{array}$ \\
\hline 3. Distribution & $\begin{array}{l}\text { - What sort of problems are addressed and whose problem defi- } \\
\text { nitions are being used? } \\
\text { - What vulnerabilities can be identified in this neighbourhood } \\
\text { that might be affected as a result of the interventions? } \\
\text { - What are the expectations of different stakeholders with regard } \\
\text { to the distribution of 'goods' and 'bads' as a result of the inter- } \\
\text { ventions? }\end{array}$ \\
\hline 4. Capabilities & $\begin{array}{l}\text { - How capable of contributing to improvements for their homes, } \\
\text { neighbourhood and in terms of relations with others are resi- } \\
\text { dents? } \\
\text { - What capabilities and competence are needed for residents to } \\
\text { participate in the process in a meaningful manner? }\end{array}$ \\
\hline 5. Responsibility & $\begin{array}{l}\text { - How is the issue of taking responsibility addressed? } \\
\text { How are the residents supported so that they are capable to par- } \\
\text { ticipate and able to take responsibility? }\end{array}$ \\
\hline
\end{tabular}

Based on Davoudi and Brooks [12].

Table 2

Categories to analyse interviews with residents.

- Me and my home

- Me and my neighbourhood

- My neighbourhood

- Me and organisations (e.g. the housing association; municipal organisations; tenants' associations; the community centre)

- My neighbourhood and organisations (e.g. the housing association; municipal organisations; tenants' associations; the community centre)

- My neighbourhood and the wider environment

We used the two strategies to better understand the sort of conditions that have affected the deflecting of the course envisaged by the housing association. The environmental justice framework as an analytical framework connects the two. Adopting the five dimensions of environmental justice allowed us to ask what type of distributional patterns occurred while attempting a demand-driven intervention. It also raises questions as to why and how these have emerged from path-dependent processes, underlying social structures and institutional contexts. In line with a situated view of environmental justice, investigating the diverse perspectives and positions involved will clarify the diversity among the residents and shed light on the local capabilities and responsibilities that residents are willing and able to take. Next we can ask how this diversity has been recognised and invited as part of the demand-driven approach.
Table 3

Empirical data collection methods.

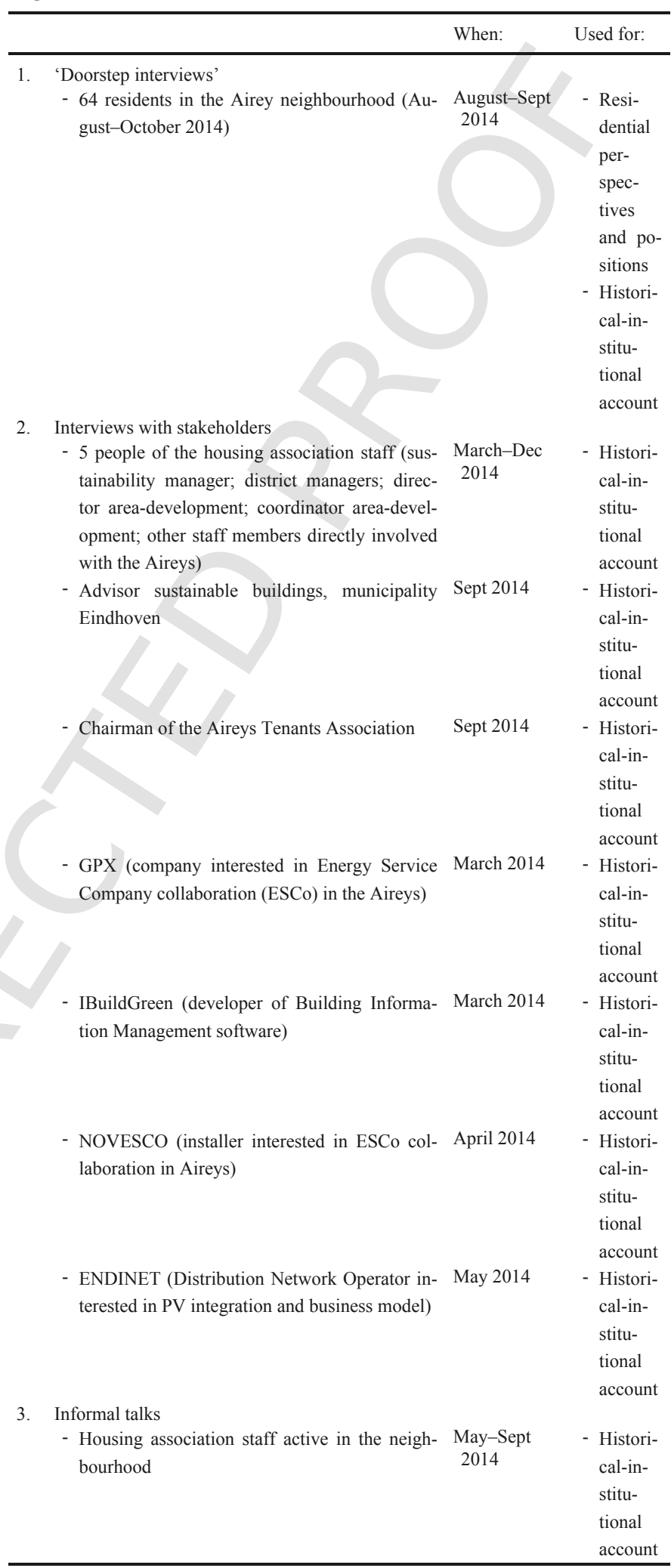


Table 3 (Continued)

\begin{tabular}{|c|c|c|c|}
\hline & & When: & Used for: \\
\hline & - Neighbourhood policy officer & Sept 2014 & $\begin{array}{l}\text { - Histori- } \\
\text { cal-in- } \\
\text { stitu- } \\
\text { tional } \\
\text { account }\end{array}$ \\
\hline & $\begin{array}{l}\text { - Members of the tenants association (several } \\
\text { times when visiting the neighbourhood, each } \\
\text { time meeting with } 1-5 \text { people) }\end{array}$ & Sept 2014 & $\begin{array}{l}\text { - Histori- } \\
\text { cal-in- } \\
\text { stitu- } \\
\text { tional } \\
\text { account }\end{array}$ \\
\hline & - MGE (Professional Energy Cooperative) & July 2014 & $\begin{array}{l}\text { - Histori- } \\
\text { cal-in- } \\
\text { stitu- } \\
\text { tional } \\
\text { account }\end{array}$ \\
\hline & $\begin{array}{l}\text { - Woonconnect (developer of Building Informa- } \\
\text { tion Management software) }\end{array}$ & Oct 2014 & $\begin{array}{l}\text { - Histori- } \\
\text { cal-in- } \\
\text { stitu- } \\
\text { tional } \\
\text { account }\end{array}$ \\
\hline 4. & $\begin{array}{l}\text { Participant observations during meetings } \\
->5 \text { meetings with housing association staff and } \\
\text { others (e.g. MGE the energy cooperative) where } \\
\text { the plans for the Aireys were discussed }\end{array}$ & $\begin{array}{l}\text { April-July } \\
2014\end{array}$ & $\begin{array}{l}\text { - Histori- } \\
\text { cal-in- } \\
\text { stitu- } \\
\text { tional } \\
\text { account }\end{array}$ \\
\hline 5. & $\begin{array}{l}\text { Documentation } \\
\text { - Policy documents from housing association } \\
\text { Woonbedrijf, municipality, province, regional } \\
\text { smart city and green deal initiatives, national } \\
\text { policy, etc.; website information; powerpoint } \\
\text { presentations from stakeholders; local newspa- } \\
\text { per clippings, etc. }\end{array}$ & & $\begin{array}{l}\text { - Histori- } \\
\text { cal-in- } \\
\text { stitu- } \\
\text { tional } \\
\text { account }\end{array}$ \\
\hline
\end{tabular}

\section{The Aireys: a walk down memory lane}

Our empirical case tells the story ${ }^{3}$ of a deprived neighbourhood that was targeted by the housing association and municipality to become a textbook example of sustainable neighbourhood transformation and local self-governance, in terms of process and outcome. Housing association Woonbedrijf introduced this so-called "Neighbourhood Transformation" (NT) approach as very innovative. Central elements included first of all a neighbourhood renovation for more energy-efficient homes (enhancing the quality of the housing stock; preventing energy poverty). A second element entailed neighbourhood-owned and managed Photo Voltaic (PV) rooftop panels. Thirdly, the initial two elements were to be accomplished through a socially transformative process that would result in more social cohesion and improved public spaces. Thus the focus would be on sustainability and comfort, lowering the cost of living and improving the living environment.

The NT approach was to be piloted in the Airey neighbourhood (also called 'the Aireys'), a small post-world war II neighbourhood located in the south-west of Eindhoven, a city in the Dutch province

\footnotetext{
${ }^{3}$ We refer to [7] for the elaborate report.
}

of Brabant. The name refers to the architect Sir Edwin Airey, ${ }^{4}$ who designed homes that were easy to build using a system of prefab steel frameworks filled with concrete building blocks. In various Dutch cities, the post-war need to quickly provide social housing prompted the use of this type of building. A total of 238 houses and 56 apartments were built in the Aireys. The energy efficiency of these houses is very poor, with Energy Performance label E (on a scale of $\mathrm{A}^{+++}$to $\mathrm{G}$, with $\mathrm{G}$ being the lowest level) [5,6]. Around 2014, the household energy bill in the Aireys averaged 145 euros a month, which is high considering the small size of the homes [5].

\subsection{Philips: more than just a company}

Philips, the multinational electronics company that started out in Eindhoven in the 19th century, has left its mark on Eindhoven in many ways. Of the older residents in the Airey neighbourhood, 19\% have lived there since Philips built these homes for its production-line workers in the 1950s. At that time one of the biggest employers in Eindhoven, Philips contracted the building of the Aireys, established its own social housing association, and provided a host of other public services (e.g. soccer team). Philips ensured that the Airey neighbourhood remained as it was for a long time: a socio-economically homogenous neighbourhood with close-knit social relations. However, in the 1980 s, globalisation and increasing competition prompted Philips to reorganise and move production facilities elsewhere. Slowly but surely, Philips' grip on the city loosened.

Today, the overall picture of the Aireys is very different. Philips' housing organisation became a public housing association. The neighbourhood has become much more diverse and less well-off compared to the Philips era. Social-economic problems, indebtedness, low disposable income, unemployment, low educational levels, loneliness, health issues (e.g. obesity and mental problems) and lack of perspective and commitment to the neighbourhood are nowadays characteristic of the Aireys [16,17,32]. In fact, the small group of elderly ex-Philips workers still has the highest level of social networking.

\subsection{The Aireys: build for demolition but here to stay}

Although demolition would have been cheaper and less hassle than retrofitting these homes, this did not happen. In 2004, Eindhoven's Airey homes received a special status: thanks to their specific characteristics, they were considered worth protecting and thus worthy of restoration and retrofitting instead of demolition. ${ }^{5}$ Although this was not a formal institutional arrangement stipulating legal preservation, it nevertheless influenced the decision to save the larger part of the Aireys. Another institutional arrangement that prevented Woonbedrijf from completely demolishing the Aireys stemmed from the legal obligation $^{6}$ to maintain a certain percentage of homes within the cheapest rental segment.

\subsection{Ambitions become pressures}

Interventions aimed at renovation and energy efficiency improvements in the Aireys were closely related to other (municipal and national) policy domains, such as social housing, social and regeneration policies and energy policy. Back in 2000, and following national

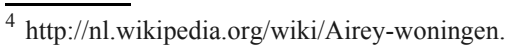

5 'Beschermd stadsgezicht'. Retrieved from http://www.architectenweb.nl/aweb/ redactie/redactie_detail.asp? $\mathrm{iNID}=36422$ (accessed 5.10.15).

${ }^{6}$ Housing Regulation (huisvestingsverordening) and Housing Act (Woningwet)
} 
policy, Eindhoven municipality designated the Aireys as an 'action district' - meaning that specific physical and/or social deprivations exist and that efforts are needed to enhance liveability [32,18]. The regeneration would be in two phases, the first targeting social regeneration and the second addressing the physical renovation of homes and the neighbourhood. Woonbedrijf's decision to choose this neighbourhood to start a process targeting not only the energy efficiency of the homes, but also social and individual needs, fitted well with this policy. In the course of time, the ideas for the Aireys further evolved in policy processes at different levels - municipal, regional and national - where goals, visions, targets were formulated by stakeholders such as the municipality, regional government and technology actors.

Stakeholders in the municipality, Woonbedrijf and others formulated strategic sustainability goals for Eindhoven. An Energy Roadmap was developed to achieve the municipal target of an 'energy-neutral Eindhoven' by 2045, with a strong primary focus on the built environment [14]. Woonbedrijf decided to substantially improve the energy efficiency of its housing stock and upgrade approximately 5000 homes in Eindhoven to energy label B. Various (policy) documents mentioned the Aireys as a showcase and pilot for a living lab, e.g. $[27,14,38,4550]$. The Neighbourhood Transformation (NT) approach was mentioned as a way to mobilise hitherto uninterested and unengaged residents.

The ideas for an NT approach in the Aireys were adopted by governance networks in their overarching stories about techno-economic innovation and energy-neutrality. These historically evolved networks consisted of local and regional government, innovative companies and their knowledge (strongly connected to Eindhoven University of Technology which plays an active role in these networks) and other (semi)public organisations like Woonbedrijf. Within these networks, technology developers were invited to propose business cases, leading to ideas for a neighbourhood-owned Energy Service Company (ESCo). Rooftop solar panels would be needed to raise the Airey homes to energy label B. However, a housing association is legally not allowed to distribute energy, which explains Woonbedrijf's interest in residents owning the ESCo. This could then, in theory, also become a vehicle for other local services (e.g. collective purchase of insurance), thus lowering the cost of living and/or making funds available for collective neighbourhood-level goals such as improved public spaces, playgrounds. However, none of the residents was invited to participate in developing these ideas or their assessment. Options for an energy cooperative were also investigated because local generation, storage and distribution are subject to complex tax rules. The company investigating this concluded that no positive business case appeared feasible.7

\subsection{The Neighbourhood Transformation approach}

The NT approach was to achieve sustainability and comfort (e.g. ventilation), a reduction in the cost of living and improvement of the neighbourhood in general. It had been kick-started in 2013 with an expert workshop addressing the question How to combine neighbourhood restructuring with sustainability and energy saving? Additional expert sessions expanded the demand-driven focus to 'getting to know and understand' the neighbourhood. Despite the intended demand-driven approach, the residents were not actually part of the process of shaping this first step in the NT approach. In other words, they were not involved in co-producing the NT rules-of-the-game.

Various 'tools' were deployed aimed at getting to know and engage the neighbourhood:

\footnotetext{
${ }^{7}$ At the time of writing, a new construction with an external operator is being investigated.
}

- A survey addressing issues like solar panels, sustainability, energy, public spaces.

- An exemplar home in the neighbourhood, retrofitted with PV panels and a display.

- The exemplar home functioned as a 'street chamber' that could be used as a meeting place for the existing tenants association, residents, welfare workers, police, neighbourhood concierge etc.

- A neighbourhood manager was assigned as the spokesperson for Woonbedrijf in the Aireys (welcoming residents and organising activities with and for the residents and the neighbourhood).

- The Woonconnect tool was developed, a 3D Building Information Management (BIM) software application to assist residents in choosing renovation options.

While some of the tools were appropriate, they could not replace actual interaction with all the residents. The survey gave no insight into who was thinking what and why. The hope that the tenants association would function as a representative for the neighbourhood did not materialise. The street chamber was not a great success as only a small percentage of the residents (notably the tenants' association members) visited the place. The BIM software tool was meant to provide a feeling of having choices as it gave residents additional renovation options alongside the obligatory package (wall insulation and other energy efficiency measures) such as a new front door. It could provide insight in the energy performance of the home and show how renovation measures can contribute to comfort, safety and aesthetics. Woonbedrijf's message accompanying the launch of the BIM tool was that on average the increased rent would be offset by the reduced energy bill (thanks to the homes' enhanced energy performance). This shows the lack of recognition of diversity that is characteristic for how distributional issues are presented to social housing residents [9]. In practice, there are no average users: some residents will gain and others will lose. People who already use very little energy run the risk of overall higher costs. However, rather than addressing this distributional risk in a transparent manner, the package was to be presented as a win-win situation for all.

Consequently the aim to place the residents at the centre and let them co-shape the innovations, had watered down into a conventional attempt to gain acceptance for a renovation that was planned and designed by Woonbedrijf, using various tools in a rather instrumental way. Woonbedrijf had great difficulty in giving residents a real voice in the process, partially because the goals had already been set by higher policy levels. The 'moment of truth' - organising an activity to start the co-creation with residents - was postponed over and over again, with Woonbedrijf arguing that it felt it had to be able to present a more concrete proposition for the residents. In all likelihood, there were worries that the residents would not show the necessary acceptance levels.

\subsection{Aireys: heavy weight of contradicting expectation}

The NT approach was not so much based on the residents' actual demands, but conditioned by institutional arrangements, directed by other political agendas and based on expert opinions identifying residents' needs. A course of action was envisaged, expressed and reproduced time and time again, featuring the Aireys as a 'living lab' showcasing innovative (energy) technologies. High expectations were created, to the extent that people were talking about the Aireys as a success model before anything had actually started! The path-dependent processes in various domains and at various levels limited the amount of room for a locally informed process of neighbourhood improvement. Housing association Woonbedrijf had become locked-in in this process of rising expectations, while the actual en- 
gagement with the residents was being postponed over and over again. Neglecting 'the rules of the game' and the resulting lack of a clearly defined process led to ad-hoc decisions (often to postpone engagement with the residents). Having heard only rumours, residents were put off by the process due to lack of clarity, being ill-informed and distrust because of a lack of transparency to weigh up risks and benefits. No (clear) process means there is no room for discussion (or negotiation) about the conditions and types of interventions that would be acceptable for the residents. Moreover, if the residents are considered part of the solution - becoming actively engaged in the improvement of their neighbourhood - they need to be part of the formulation of the rules that guide the process towards neighbourhood improvement. However, they came to be regarded more as a problem than part of the solution.

The analysis in this section reveals the processes and conditions that have undermined the social recognition of the residents, thereby also compromising the opportunities for meaningful participation in discussions on distributive issues. Solutions developed for a deprived neighbourhood scarcely bore in mind their suitability for the specific neighbourhood context. As such, the city of Eindhoven, where historically evolved stakeholder networks draw up visions, agendas, roadmaps and prepare interventions, has functioned as a socio-political space that reproduced patterns of exclusion and non-recognition rather than offering room for opening up [2].

\section{The aireys according to the residents}

Late 2014, Woonbedrijf realised that the NT approach in the Airey neighbourhood was not taking off, the street chamber was not widely visited, the Woonconnect BIM-tool was not yet deployed, and Woonbedrijf faced lack of engagement and momentum [7]. At this moment our proposal to conduct interviews in the Aireys was accepted by Woonbedrijf, hoping for a way out of the impasse. Below we present the analysis of the residents' perspectives, based on fieldwork performed for Woonbedrijf at the end of 2014 [28].

During the brief doorstep-interviews, residents were asked how they were doing, what they liked and disliked about their homes and the neighbourhood [7]. The aim was to better understand the residents' opinions on their own homes, the social dynamics in the neighbourhood, the quality of public spaces and their relationship with the housing association or other organisations. In Section 5.2 we present our analysis of the interviews using the categories in Table 2. But first we present four broad segments identified as a first starting point for recognizing the diversity in the neighbourhood.

\subsection{Married to the neighbourhood or eager to leave}

Based on the interviews, we identified four segments: Backbone Seniors, Inflow Seniors, Transfer Residents and DOOR Candidates, which we briefly describe below [7,28].

\subsubsection{Backbone seniors}

These residents have been living in the Aireys since the beginning and most of them used to work for Philips. Many hold on to their (old) social norms - for instance when it comes to maintaining your front garden. They characterize the neighbourhood as deteriorating and some implicitly blame Woonbedrijf since it allocates the houses to the 'wrong' people and does not properly maintain the public green spaces. Some backbone seniors are willing to help other residents to some extent, but do not wish to help neighbours who 'should be able to help themselves'. They still know many other seniors in the neighbourhood and their social network is spread over the entire neighbourhood - which is not the case for the other segments. These seniors look back on the old days with a bit of nostalgia, when people knew each other well ('we even knew what sort of pet each home had') and would drink coffee together. Moreover they worry about forthcoming renovation plans because of the potential inconvenience, but also fear that their self-made home improvements (e.g. alterations to the building or heating and cooling systems to enhance the living space and increase comfort) will not survive the renovations.

\subsubsection{Inflow seniors}

These residents are in the same age group as the backbone seniors, but they moved to this neighbourhood somewhat later and are not really part of the same social network. Some fit in with the other seniors but many tend to keep to themselves. They do not share all the social norms of the backbone seniors. In fact, some of them feel discriminated by other neighbours and/or even have conflicts with them. A few respondents regularly visit the community centre to play cards, billiards or dance, but many others explicitly avoid this centre.

\subsubsection{Transfer residents}

This is the largest segment, mainly consisting of single-person households, single mums, young starters and young small families. Many hope to move to a better neighbourhood, mentioning of the poor state and especially the small size of their homes as main reasons. This is strengthened by the comparatively good state of the houses in surrounding neighbourhoods which have been refurbished or renewed. At the same time, many are not very positive about the renovation plans and the ensuing inconvenience. Giving nuance to this picture is the fact that some transfer residents indicate that they might actually consider staying if only they could enlarge or improve their homes. They do mention aspects of the neighbourhood that they appreciate (e.g. its green, quiet, good location). Also, many transfer residents will not be able to move due to limited financial means. Unlike others, they have not really succeeded in improving their home so that it feels like their 'own' place. In addition, they have invested little in building up social relations in the neighbourhood and feel little commitment to the Aireys.

\subsubsection{DOOR candidates}

DOOR refers to the organisation that supports people who, after a period of problems, now have the opportunity to make a fresh start in the Aireys. They need time to learn how to deal with everyday life as well as their personal problems. In most cases they live quite isolated from others and have not been able to build up their own social network in the neighbourhood. Some of them moreover do not feel welcome and accepted in the Aireys (e.g. have problems with their neighbours).

\subsection{Views on home, street, neighbourhood and others}

We have structured this section using the categories that we used in our attempt to reconstruct residents' perspectives (Table 2).

\subsubsection{Me and my home}

The respondents mentioned various needs and wishes regarding improvements to their individual homes. The most frequently listed shortcomings and defects included:

- The homes are small

- The homes are uncomfortable (hot in summer, cold in winter, draughts from windows and/or doors, damp; smells spread between the houses; the homes are noisy; the toilet is very small; dislike the 
grey colour of the homes; windows difficult to open and to clean; vulnerability to burglary)

Surprisingly, many considered heat stress during the summer a bigger problem than the cold in winter. Several respondents have installed air conditioning themselves and many have taken measures against draughts (curtains; weather-strips and towels on the windowsills). When asked, very few respondents expressed interest in saving energy. The high interest in insulation did not relate to energy saving but comfort considerations.

Regarding solar panels, respondents indicated that they only want these if they are profitable. Most were explicit about not wanting to take any financial risk with these - since they cannot afford such risks. Some people indicated that they are too old for solar panels. Others asked rhetorically what the point of all the hassle is if the reduced energy bill is offset by the increases in rent. It furthermore became clear that the display in the exemplar home showing the energy generated by the rooftop solar panels is not well understood by many residents.

\subsubsection{Me and my street}

Respondents indicated that the social networks in the Aireys are often very local, at street level and with direct neighbours (greet each other, sometimes have a chat, watch out for each other, and in some cases occasional visits). Some said that they help neighbours maintain their garden and with chores. However, this picture varies considerably in each segment.

\subsubsection{Me and my neighbourhood}

Most residents indicated little interest in taking an active role in a local initiative or in a collective approach to improve the neighbourhood. Several expressed a lack of confidence that a collective approach could work in a neighbourhood like the Aireys. When asked, many respondents indicated that they were not interested in participating in additional neighbourhood activities besides the annual market, which is very popular. At the same time, several expressed their willingness to help neighbours. Others stated that they do not have the time to help others (Transfer Residents), that they would like to, but are not able (due to physical constraints), that they already do some kind of volunteer work, or that they are simply not interested. Quite a few elderly and DOOR candidates themselves are actually in need of help from neighbours, family or organisations.

\subsubsection{The neighbourhood}

Reasons mentioned for the deterioration of the Aireys included the fact that many new residents do not plan on staying for long; others do not speak Dutch; yet others (DOOR candidates) have personal problems. The increased diversity has resulted in clashes in social norms e.g. about properly maintaining your front yard which also means that you do not pave it with tiles. The perceived deplorable state of many front yards was regarded by a lot of respondents (not only the Backbone Seniors) as an indicator of a more general downward trend, but also ill-maintained public green spaces. Several respondents felt that the municipality and Woonbedrijf should put more effort into maintaining green public spaces.

\subsubsection{Me and organisations}

Most residents assessed their relationship with Woonbedrijf as overall good. However, some (implicitly) blamed Woonbedrijf and/or the municipality for the perceived degradation of the neighbourhood. Neither the street chamber nor the community centre are frequently visited by large numbers of respondents - many feel not represented and sometimes even not welcome there.

\subsubsection{Neighbourhood and organisations}

Respondents overall indicated that they felt ill-informed, let alone actively involved in any sort of intervention. Most had no idea that a Neighbourhood Transformation approach was being prepared, however some had heard rumours of planned renovations. Many respondents expressed their need for more information about the forthcoming renovation plans and felt that Woonbedrijf had fallen short in communicating properly with the residents.

\subsubsection{Neighbourhood and wider environment}

Several residents pointed out that homes in the surrounding neighbourhoods are in better shape. There, houses have been demolished and rebuilt or nicely renovated, while the rent is only slightly higher. This has strengthened the feeling of injustice and desire to move. Several respondents argued that the homes in the Airey neighbourhood should be demolished rather than renovated, also because it would not be cost-efficient to invest so much money in such old houses.

Both the segmentation and residential views on their daily living environment reveal context-specific information that points towards directions for co-developing a tailored intervention for and with the neighbourhood, as the next section will show.

\section{The environmental justice framework as an instrument}

We will discuss how, in spite of the institutional lock-ins set out in Section 4, a more demand-driven approach can be adopted, using the environmental justice framework. Table 1 listed the relevant questions to gain an overall assessment of the five dimensions of the environmental justice framework in the Neighbourhood Transformation approach.

An initial observation is that the process started off on the wrong track with a lack of recognition of the residents by not including them in the development of the NT approach. In addition, although various tools were deployed, these did not help to provide clarity on the diversity of participants or their needs and aspirations. The Aireys is no longer the close-knit working-class neighbourhood it once used to be, which makes the focus on differences in needs even more crucial. The interview analysis made it clear that many Airey residents did not feel that their needs, perspectives and wishes were recognised by Woonbedrijf. The focus has been mainly on energy saving, while this is not considered important by most residents. Our fieldwork demonstrated needs around heat and cold management and regarding safety, social cohesion, maintenance of public spaces and front yards. In addition, we can identify at least four broad segments of tenants who differ not only in terms of their needs, but also their capabilities to partake in any regeneration process. Recognising these segments and involving each of them in the process provides a starting point for a demand-driven process.

Woonbedrijf had no clear idea on how to engage residents with diverse needs and ambitions to have them participate in the further design and implementation of the transformative approach - partly because the goals had already been set and partly because of the natural pitfall of wanting to be able to propose concrete actions before involving residents. This reinforced the residents' feeling that Woonbedrijf was planning this intervention mainly for their own gain and that there was a catch to the renovation; many saw the increased rent as that catch. The process did not encourage residents to play an active role in the improvement of their neighbourhood; they did not feel they were participating at all. Instead, they felt ill-informed, having heard some rumours but had no idea of what the next steps and interventions in the neighbourhood would entail and when to expect 
them. In addition, the existing tenants association, supported by the housing association to encourage community building, and used as representative for the neighbourhood, was not attractive for most residents, who did not feel represented by that group, thus increasing the feeling of not being recognised nor able to participate.

Distributional issues were addressed but not from the residents' viewpoint. The concrete issues that the NT approach planned to address did not match the issues experienced by residents. Many were distrustful of the distribution of costs and benefits of the interventions planned by the housing association (whatever these would entail). There was no discussion with residents, no participation in the decision-making process around tools such as Woonconnect, and consequently no clarity on the transfer of risks for the energy performance of the renovated homes.

Woonbedrijf's explicit intention to upgrade some 5000 homes in Eindhoven to energy label B combined well with policy ambitions from other domains and stakeholders. More and more, the Aireys appeared to be the perfect candidate for a radical innovative trajectory. The mind set was based more on their ambitions rather than a realistic assessment of the Airey residents' potential capabilities. The increasingly heterogeneous demographics, tensions between old and new residents, a lack of social cohesion, non-existent or increasingly small and local social networks, all posed serious challenges for a collective approach resting on residents' capacities. Relations first need to be built as part of a capacity building process. The expertise to set up an energy cooperative is hard to find in general, let alone in such a deprived neighbourhood. There was also no desire to adopt responsibility for an energy cooperative among residents who are struggling with responsibilities related to life in general. However, some residents expressed an interest in neighbourhood-level activities - helping the elderly for example. The transfer residents segment includes those who can make valuable contributions to neighbourhood improvements. They might be willing to take responsibility. We have seen that not all of them are equally negative, moreover it is unlikely that many will be able to move to another home soon.

In order to encourage residents to play an active role in their neighbourhood, it is important that they want to live and stay in the Aireys. To achieve that, their wishes and needs regarding their homes (e.g. comfort, appearance, lower vulnerability for burglary) and neighbourhood (e.g. front gardens, public green spaces but also social activities not linked with the tenants association) must be recognised.

The example of the Aireys shows how an explicit aim to shape an intervention for a more sustainable neighbourhood in a manner that guarantees the residents' genuine and meaningful participation, is a necessary but not sufficient condition to achieve a good process, let alone a successful outcome. The absence of higher-level institutions supporting a more polycentric (as opposed to a uni-centric and hierarchic) approach means that local self-governance is not enabled, supported and institutionalised. However, even while path dependencies and institutional lock-ins are likely to undermine demand-driven approaches, an active process of local capacity building, based on the five dimensions of environmental justice, can counter this. Following Davoudi and Brooks [25], this has been investigated and tested in the Aireys. ${ }^{8}$ The questions posed in Table 1 can be regarded as guidelines to support such a process. An environmental justice approach helps when compiling the relevant questions for the preparation, design, implementation and evaluation of interventions. It can also help prevent disappointment on all sides, enabling a more realistic assessment of what can be expected in the short to medium term by providing insight in the local social potential. It can be a very useful instrument to

\footnotetext{
${ }^{8}$ See also [7].
}

investigate the conditions for local self-governance and how to address these in a participatory intervention, given certain institutional lock-ins.

Based on the interviews, Woonbedrijf has in fact adapted its approach, after being better informed about residents' needs and viewpoints. Woonbedrijf has skipped several of the ambitious energy-related goals and started focusing on the neighbourhood and its residents, developing renovation packages devised to fit the expressed needs, allowing for and enabling the participation of all residents. Whether this will actually result in new practices in this and other neighbourhoods remains to be seen, but so far the application of the environmental justice framework seems to have been fruitful.

\section{Towards institutional lock-out: building institutional capacity for local self-governance}

The aim of this paper was to address how an externally initiated programme can succeed in starting and supporting a local capacity building process for self-governance - particularly in local contexts where such capabilities are absent. We discussed how good intentions can be compromised as the initiators of such programmes get locked into path-dependent processes that define the course of action through reproducing techno-oriented visions and agendas that are promoted by various stakeholders but not compatible with local demand-driven approaches.

We started asking what type of challenges an externally initiated programme faces when attempting a more demand-driven approach. Attention to path-dependencies and institutional lock-ins helps us understand why certain outcomes are not simply the result of an intentional strategy. We developed a context-sensitive perspective on sustainable innovation efforts, pointing out how certain 'choices' are shaped even though they counteract initial objectives. The focus on options for local self-governance which the socio-ecological systems literature stresses, has been relevant to reveal the importance of higher-level institutions which enable or hinder local socially innovative institutional arrangements. In addition to the ex-post historical analysis, we also inquired into the diverse locally situated views and positions, to find that these have not been recognised in the design and implementation of the interventions. One crucial issues that our analysis revealed was a local lack of initial interest in energy saving issues. However, that does not mean there was no interest in neighbourhood improvements. Rather it shows that if energy and ecological sustainability are the only ingredients of an intervention aiming to be participatory, then this is not likely to work. Instead, with the support of the Environmental Justice framework, other needs and aims can be identified and included as well, so that a locally defined sustainability concept is shaped as part of the intervention design and implementation.

In order to prevent an externally initiated programme from diluting into a top-down technology-pushed approach, we propose an active process of local capacity building, using an environmental justice approach to investigate the conditions for local self-governance and how to address these in a participatory intervention.

The relevance of assessing efforts like the Neighbourhood Transformation programme in the Aireys goes beyond this particular case. Where grass-roots initiatives are being heralded across Europe as new socially innovative niches that will contribute to a more sustainable (and just) energy system and society, there is also another side to this story: those places where no grass-roots initiatives occur. Many neighbourhoods have become trapped in a downward spiral where socio-economic opportunities are declining, facilities provided by the former welfare state have been abolished and where the quality of life 
is under pressure. Reversing a downward spiral that has evolved (and co-evolved with institutions and greater trends) over a period of decades is not likely to happen through a single intervention or programme overnight. Power not only lies with people or organisations, but also in solidified structural conditions that are locked-in and hard to change.

The Environmental Justice framework can be a starting point for achieving a lock-out from technology-dominant top-down 'innovation' trajectories. It starts with an awareness of the seemingly self-evident perpetuation of certain dominant ways of doing and thinking, through a recognition of the diverse ('other', end-user focused) ways of doing and thinking. This then needs to be followed by efforts that challenge the sources of lock-in, opening up the innovation trajectory and improving the quality of the participation. Allowing for the time and effort required to build local capacities so that end-user or citizens can meaningfully participate, is a first step in a co-creation process towards local sustainability improvements that also generate benefits for those whose vulnerable position in part formed the reason to start the intervention.

\section{Uncited references}

$$
[3,6,8,17,39,45] \text {. }
$$

\section{Acknowledgements}

We thank the reviewers for their constructive comments that have been of great help to improve this paper. The research on which this paper is based was funded by the Dutch Ministry of Economic Affairs (Subsidieregeling energie en innovatie (SEI), Topsector Energie executed by RVO (Rijksdienst voor Ondernemend Nederland)).

\section{References}

[1] C. Behar, L. Chui, Ventilation in energy efficient UK homes: a user experience of innovative technologies, ECEEE Summer Study Proceedings (2013) 2389-2399.

[2] D. Bell, S. Davoudi, Understanding justice and fairness in and of the city, in: D Bell, S. Davoudi (Eds.), Justice and Fairness in the City. A Multi-Disciplinary Approach to 'Ordinary' Cities, Policy Press, Bristol, 2016.

[3] B. Bickerstaff, G. Walker, H. Bulkeley, Energy in a Changing Climate Social Equity and Low-Carbon Energy, Zed Books, London, New York, 2013

[4] N. Blaikie, Designing Social Research: The Logic of Anticipation Paperback, Policy Press, 2000.

[5] R. Bogaards, Neighbourhood Transformation approach in the Aireys [Buurttransformator in het Aireygebied], Presentation for 'Meet and Greet Energy Transition', Woonbedrijf, Eindhoven, 2013 (in Dutch).

[6] R. Bogaards, Connecting Sustainably [Duurzaam verbinden: in de slimste regio mag verduurzamen nooit het probleem zijn], Ptt Presentation for 'Platform Economie en Ruimte', Woonbedrijf, Eindhoven, 2013 (in Dutch).

[7] S.C. Breukers, R.M. Mourik, L.F.M. Van Summeren, G.P.J. Verbong, Giving Voice to Residents. Environmental Justice and Sustainable Transformations of Dutch Social Housing Neighbourhoods, 2016. Eindhoven. March 2016. Can be retrieved from http://www.duneworks.nl/project-nl/stem-de-buurttransformator/.

[8] S. Breukers, P. Upham, Organisational aspects of public engagement in European energy infrastructure planning: the case of early-stage CCS projects, J. Environ. Plan. Manag. 58 (2) (2015) 252-269, http://dx.doi.org/10.1080/ 09640568.2013.851597.

[9] S. Breukers, L.M.F. van Summeren, R.M. Mourik, First Process, Then Performance. (Eerst proces, dan Prestatie. Naar een optimale afstemming tussen aanbieders, bewoners en de woning in renovaties richting energieneutraliteit.), 201440 (Platform 31/Energiesprong).

[10] S. Breukers, M. Wolsink, Wind power implementation in changing institutional landscapes: an international comparison, Energy Policy 35 (5) (2007) 2737-2750, http://dx.doi.org/10.1016/j.enpol.2006.12.004.

[11] S. Davoudi, E. Brooks, When does unequal become unfair? Judging claims of environmental injustice, Environ. Plan. A 46 (11) (2014) 2686-2702, http://dx. doi.org/10.1068/a130346p.
[12] S. Davoudi, E. Brooks, Urban greenspace and environmental justice claims, in: D. Bell, S. Davoudi (Eds.), Justice and Fairness in the City. A Multi-Disciplinary Approach to 'Ordinary' Cities, Policy Press, Bristol, 2016.

[13] R. Dam, M. van Duineveld, R. During, Delineating active citizenship: the subjectification of citizens' initiatives, J. Environ. Policy Plan. 17 (2) (2015) 163-179, http://dx.doi.org/10.1080/1523908X.2014.918502.

[14] E. Den Ouden, R.D. Gal, Vision and Roadmap Eindhoven Energy-Neutral 2045. Research Report Energy in the Built Environment - June 2014, The Intelligent Lighting Institute at the TU/e, for and in partnership with the City of Eindhoven and Woonbedrijf, Eindhoven, 2014.

[15] T. Dietz, E. Ostrom, P.C. Stern, The struggle to govern the commons, Science 302 (5652) (2003) 1907-1912, http://dx.doi.org/10.1126/science.1091015.

[16] Eindhoven Municipality, Analysis and Needs Action Areas 2015-2018 [Analyse en Opgaven Actiegebieden 2015 t/m 2018], Eindhoven Municipality and the housing associations Eindhoven 'thuis, Trudo Woonbedrijf and Wooninc, 2014 (in Dutch)

[17] Eindhoven Municipality, New Vision on Housing and Living [Manifest Nieuwe Woonvisie Eindhoven], 2014 (in Dutch).

[18] Eindhoven Municipality: Letter from the Municipal Council, Raadsinformatiebrief plan van aanpak gebiedsgericht werken: methodiek van buurtanalyse en aanwijzing van gebieden voor een gebiedsgerichte aanpak, (in Dutch).

[19] S. Fuller, D. McCauley, Framing energy justice: perspectives from activism and advocacy, Energy Res. Soc. Sci. 11 (January) (2016) 1-8, http://dx.doi.org/10. 1016/j.erss.2015.08.004

[20] F. Geels, From sectoral systems of innovation to socio-technical systems, Res. Policy 33 (2004) 897-920, http://dx.doi.org/10.1016/j.respol.2004.01.015.

[21] A. Goldthau, Rethinking the governance of energy infrastructure: scale, decentralization and polycentrism, Energy Res. Soc. Sci. 1 (2014) 134-140, http://dx. doi.org/10.1016/j.erss.2014.02.009.

[22] A. Goldthau, B.K. Sovacool, The uniqueness of the energy security, justice, and governance problem, Energy Policy 41 (2012) 232-240, http://dx.doi.org/10. 1016/j.enpol.2011.10.042.

[23] C. Gross, Community perspectives of wind energy in Australia: the application of a justice and community fairness framework to increase social acceptance, Energy Policy 35 (5) (2007) 2727-2736, http://dx.doi.org/10.1016/j.enpol.2006. 12.013 .

[24] P.A. Hall, R.C.R. Taylor, Political science and the three new institutionalisms, Polit. Stud. 44 (5) (1996) 936-957, http://dx.doi.org/10.1111/j.1467-9248.1996. tb00343.x.

[25] M. Hajer, De Energieke Samenleving. Op zoek naar een sturingsfilosofie voor een schone economie, Planbureau voor de Leefomgeving (PBL), Den Haag, 201177. Retrieved from) http://www.pbl.nl/sites/default/files/cms/publicaties/ Signalenrapport_web.pdf.

[26] K. Jenkins, D. McCauley, R. Heffron, H. Stephan, R. Rehner, Energy justice: a conceptual review, Energy Res. Soc. Sci. 11 (January) (2016) 174-182, http:// dx.doi.org/10.1016/j.erss.2015.10.004.

[27] P. Lehmann, F. Creutzig, M.-H. Ehlers, N. Friedrichsen, C. Heuson, L. Hirth, R. Pietzcker, Carbon lock-out: advancing renewable energy policy in Europe, Energies 5 (12) (2012) 323-354, http://dx.doi.org/10.3390/en5020323.

[28] F. Metsemakers, Looking for Energy in the Aireys [Energie zoeken in de Aireybuurt], KAW, Eindhoven, 2014 (In Dutch).

[29] MinBZK, The Do-democracy [De doe-democratie. Kabinetsnota ter stimulering van een vitale samenleving], Ministry of the Interior and Kingdom Relations, The Hague, Netherlands, 201370.

[30] M. Ornetzeder, H. Rohracher, User-led innovations and participation processes: lessons from sustainable energy technologies, Energy Policy 34 (2) (2006) 138-150, http://dx.doi.org/10.1016/j.enpol.2004.08.037.

[31] E. Ostrom, Crowding out citizenship, Scand. Polit. Stud. 23 (1) (2000) 3-16 http://dx.doi.org/10.1111/1467-9477.00028.

[32] Rigo, Ten Years of Integrated Neighbourhood Restructuring in Eindhoven: Genderdal [Tien jaar integrale wijkvernieuwing in Eindhoven: Genderdal], 2011 (in Dutch).

[33] F. Scharpf, Games Real Actors Play Actor-Centered Institutionalism in Policy Research, Westview, Boulder, CO, 1997.

[34] D. Schlosberg, Reconceiving environmental justice: global movements and political theories, Environ. Polit. 13 (2004) 517-540.

[35] D. Schlosberg, Theorizing environmental justice: the expanding sphere of the discourse, Environ. Polit. 22 (2013).

[36] G. Seyfang, Community action for sustainable housing: building a low-carbon future, Energy Policy Spec. Sect. Carbon Reduct. Commun. Scale 38 (12) (2010) 7624-7633, http://dx.doi.org/10.1016/j.enpol.2009.10.027.

[37] G. Seyfang, A. Smith, Grassroots innovations for sustainable development: towards a new research and policy agenda, Environ. Polit. 16 (4) (2007) 584-603, http://dx.doi.org/10.1080/09644010701419121.

[38] Smart Energy Regions' Green Deal Brabant. http://www.smartenergyregions. com/Bestanden/SER_GreenDealBrabant_v3_281213.pdf, In Dutch (accessed 15.03.16). 
[39] A. Smith, T. Hargreaves, S. Hielscher, M. Martiskainen, G. Seyfang, Making the most of community energies: three perspectives on grassroots innovation, Environ. Plan. A 48 (2) (2016) 407-432, http://dx.doi.org/10.1177/ $0308518 X 15597908$

[40] B.K. Sovacool, What are we doing here? Analyzing fifteen years of energy scholarship and proposing a social science research agenda, Energy Res. Soc. Sci. 1 (2014) 1-29, http://dx.doi.org/10.1016/j.erss.2014.02.003.

[41] A. Stirling, Transforming power: social science and the politics of energy choices, Energy Res. Soc. Sci. 1 (2014) 83-95, http://dx.doi.org/10.1016/j.erss. 2014.02.001.

[42] W. Swan, R. Fitton, P. Brown, Managing behavioral risks in large scale socia housing sustainable retrofit projects in the UK, ECEEE Summer Study Proceedings (2013) 661-668.

[43] K. Thelen, Historical institutionalism in comparative politics, Ann. Rev. Polit. Sci. 2 (1999) 369-404, http://dx.doi.org/10.1146/annurev.polisci.2.1.369.

[44] D. Toke, S. Breukers, M. Wolsink, Wind power deployment outcomes: how can we account for the differences?, Renew. Sustain. Energy Rev. 12 (4) (2008) 1129-1147, http://dx.doi.org/10.1016/j.rser.2006.10.021.

[45] Topsector Energie press release. http://topsectorenergie.nl/ persbericht-green-deal-smart-energy-cities-op-de-innovatie-estafette/, November 18th 2013, In Dutch, (accessed 14.03.16).

[46] G.C. Unruh, Understanding carbon lock-in, Energy Policy 28 (12) (2000) 817-830, http://dx.doi.org/10.1016/S0301-4215(00)00070-7.
[47] I. Verhoeven, E. Tonkens, Talking active citizenship: framing welfare state reform in England and the Netherlands, Soc. Policy Soc. 12 (03) (2013) 415-426, http://dx.doi.org/10.1017/S1474746413000158.

[48] G. Walker, G. Mitchell, J. Fairburn, G. Smith, Industrial pollution and social deprivation: evidence and complexity in evaluating and responding to environmental inequality, Local Environ. 10 (4) (2005) 361-377, http://dx.doi.org/10. 1080/13549830500160842.

[49] G. Walker, N. Simcock, R. Day, Necessary energy uses and a minimum standard of living in the United Kingdom: energy justice or escalating expectations?, Energy Res. Soc. Sci. 18 (2016) 129-138, http://dx.doi.org/10.1016/j. erss.2016.02.007.

[50] Website Green Deal Brabant. http://www.smartenergyregions.com/projecten/ green-deal-brabant/informatie, In Dutch (accessed 15.03.16).

[51] M. Wolsink, Fair distribution of power generating capacity: justice, microgrids and utilizing the common pool of renewable energy, in: K. Bickerstaff, G. Walker, H. Bulkeley (Eds.), Energy Justice in a Changing Climate. Social Equity and Low-Carbon Energy, Zed Books, London/New York, 2013, pp. $116-138$

[52] WRR, Trust in Citizens (Vertrouwen in Burgers), 2012, WRR (Scientific Council for Governmental Policy)/Amsterdam University Press, The Hague/Amsterdam, 2012. 